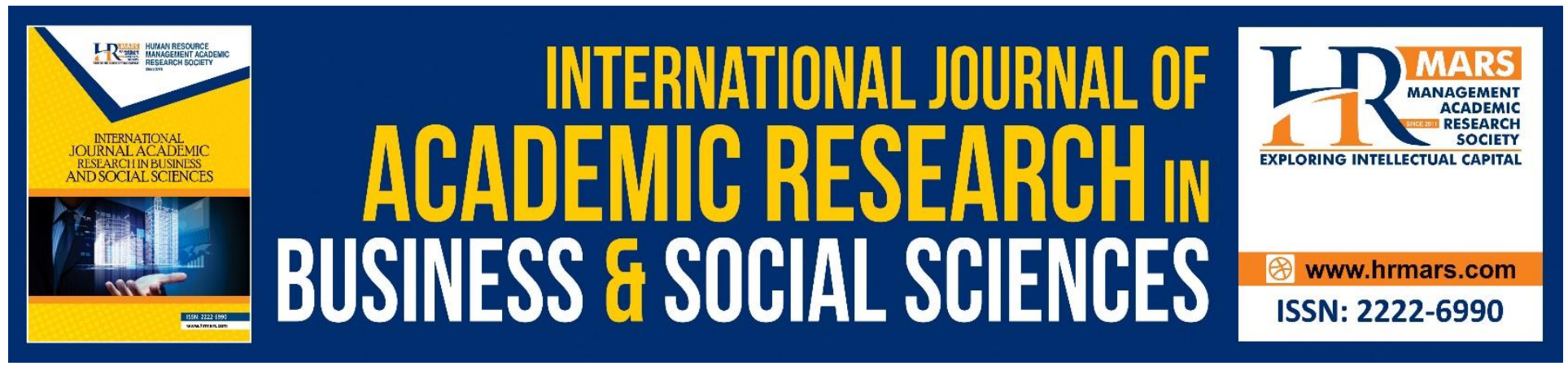

\title{
Creative and Innovative Management Culture
}

\section{Rizuan bin Zainal}

To Link this Article: http://dx.doi.org/10.6007/IJARBSS/v8-i7/4564

DOI: $\quad 10.6007 /$ IJARBSS/v8-i7/4564

Received: 27 May 2018, Revised: 24 June 2018, Accepted: 29 June 2018

Published Online: 26 July 2018

In-Text Citation: (Zainal, 2018)

To Cite this Article: Zainal, R. bin. (2018). Creative and Innovative Management Culture. International Journal of Academic Research in Business and Social Sciences, 8(7), 1165-1172.

Copyright: (C) 2018 The Author(s)

Published by Human Resource Management Academic Research Society (www.hrmars.com)

This article is published under the Creative Commons Attribution (CC BY 4.0) license. Anyone may reproduce, distribute, translate and create derivative works of this article (for both commercial and non-commercial purposes), subject to full attribution to the original publication and authors. The full terms of this license may be seen at: $\underline{\text { http://creativecommons.org/licences/by/4.0/legalcode }}$

Vol. 8, No. 7, July 2018, Pg. 1165 - 1172

http://hrmars.com/index.php/pages/detail/IJARBSS

JOURNAL HOMEPAGE

Full Terms \& Conditions of access and use can be found at http://hrmars.com/index.php/pages/detail/publication-ethics 


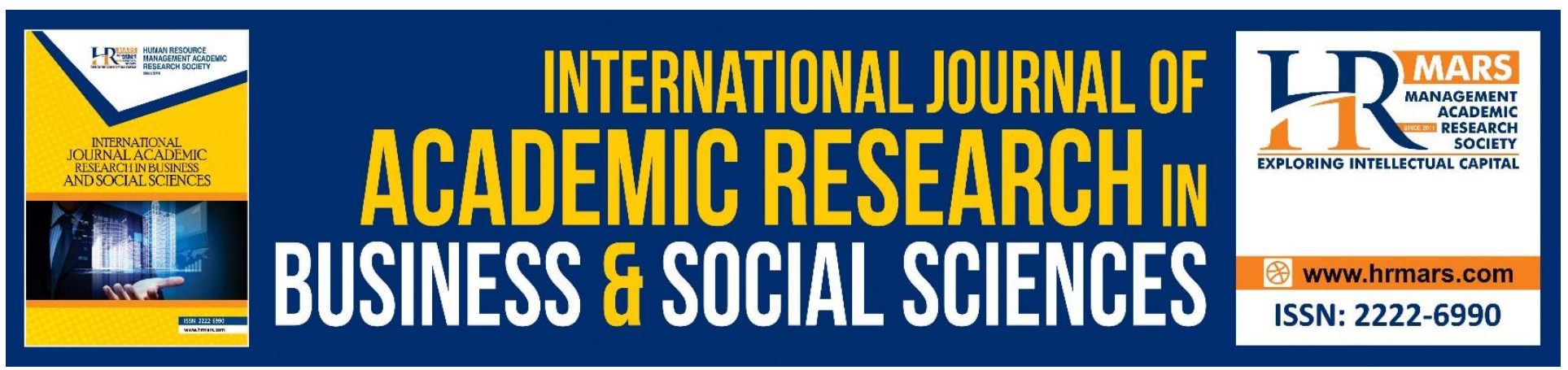

\title{
Creative and Innovative Management Culture
}

\author{
Rizuan bin Zainal \\ Kolej Komuniti Teluk Intan, 36000 Teluk Intan, Perak, Malaysia
}

\begin{abstract}
Malaysia's efforts as a developing country in preparing its citizens to become a useful human capital that is innovating and has high creativity is an indispensable requirement to be used in the development of administrative and organizational, economic and social management. The cultures of these two skills are seen as a rewarding initiative as they are able to enhance their competitiveness in their respective fields of expertise which in turn constitute the fundamental pillar of fresh and fresh ideas. This study highlights the issue of creative and innovative management practices in assisting the achievement of a sound goal in an organization. Creativity is generally the ability to find original solutions and answers to problems or challenges faced in the workplace, business, science and the arts. The cultivation of this innovation and creativity is not limited to a single community, but it must be understood and practiced by all levels of society in various fields of expertise.
\end{abstract}

Keywords: Management, Innovation, Creativity, Goals, Productivity, Services, Motivation

\section{Introduction}

Today's public and private sector sectors showcase various challenges and competitiveness in tandem with social and economic changes in modern times. Human capital development is one of the areas of concern in the development framework of the country in meeting the challenges of globalization. The rise of some Western and Asian countries that advanced a few steps ahead of Malaysia was successfully proven by the emergence of high-tech and sophisticated products resulting from the creative and innovative ideas of society from the country. For example Twitter, Whatsapp, Youtube, Facebook, iPhone, and Android are among the products that have succeeded in changing the way people today are more fun and engaging. Developed countries such as Korea, the United States and Japan that have the creativity and innovation must be an example to Malaysian society towards self development and organizational development. Hence, every level of society, especially the new generation, needs to prepare themselves with sufficient knowledge to create creative and innovative thinking towards driving developing countries in various fields and not far behind.

Research on the creation of new products and services should be based on high creativity and innovation in order to contribute to the nation's productivity and economy. Therefore, Malaysians need to develop themselves to be more creative and innovative in carrying out daily life either in performing their daily tasks or working in order to excel the development of human capital and personality. To foster creativity and innovation in an organization, proper and practical strategies and 
INTERNATIONAL JOURNAL OF ACADEMIC RESEARCH IN BUSINESS AND SOCIAL SCIENCES Vol. 8, No. 7, July 2018, E-ISSN: 2222-6990 @ 2018 HRMARS

guidance should be established. This is because large and small organizations can move and skip the goal further if the value of creativity and innovation becomes a practice in their organization.

\section{Background of Study}

Knowledge is a very important component in creating creative and innovative thinking. Kamus Dewan (1993), creativity means the ability or ability to create creative power. Innovation means creative ideas that enhance the quality and productivity of service delivery and community life. Innovation can be in the form of products, services, processes and technologies. Innovations are also defined as improvements and adaptations to existing ideas, ideas that provide new added value that can be used and utilized and can be used as products or services that can be commercialized. According to former Prime Minister Datuk Seri Najib Razak when presenting the 2012 Budget, emphasis was placed on the excellence of human capital, digesting creativity and innovating out of five key focus areas in the 2012 Budget. According to him, innovation must be adopted and practiced by all sectors, including private, public, non-governmental organizations (NGOs), parents, institutions of higher learning, schoolchildren, preschoolers (Awang, 2011).

These two elements are seen as interconnected with each other which is a basic milestone in the generation of new ideas not only to an organization but also to individuals, groups, societies and countries. In fact, 2010 was chosen as the 'Year of Innovation and Creativity' in Malaysia towards reaching Malaysia Forward 2020 (Zakaria, 2014). Healthy and competitive communities can be born with the existence of innovative individuals which in turn will be a positive and healthy competition among the people.

The innovation and creative culture is also an integral part of a leadership component. Leaders who have the power of innovation and creativity in being the main motivator of individuals in the organization because of their more motivated members of leaders who understand and appreciate what each organo member does. Employees in an organization need to be critical and constructive in carrying out their responsibilities by looking for creative and innovative solutions (Awang, 2011). The courage to try out new ideas and methods as well as out-of-the-box ideas leads to innovative and creative cultures which are a national agenda in bringing positive change to Malaysia. An organization with full commitment and involvement from top management will be able to nourish the climate and creative environment within the organization. Management style in the leadership of an organization greatly influences the development of creativity and innovation among members of the organization.

One's skills and abilities in expanding creativity and innovation can be enhanced through training. According To De Gregori (1994) there is a technique to stimulate the creative process. The creative process is usually used to find a solution to the problem, which is a challenging situation. While Pervaiz K. Ahmad (1998) stated that to promote the culture of innovation and creativity, we need to identify those who are capable in this regard through the planning, development, training and other methods that organizations need to take. There are three main factors that promote innovation and creativity, namely the individual's creative, creative thinking and motivation. Expertise refers to the competence, ability, knowledge and the special talents that a person has. Having such a thing as mentioned above will enable the individual to be able to produce creative and innovative ideas (Amabile, 1996). 
INTERNATIONAL JOURNAL OF ACADEMIC RESEARCH IN BUSINESS AND SOCIAL SCIENCES

Vol. 8, No. 7, July 2018, E-ISSN: 2222-6990 @ 2018 HRMARS

\section{Problem Statement}

Introducing creativity and innovation on new ideas in all aspects of the work to produce quality services or products. This change can be made in the form of a new technology introduction, a change in procedures that can save energy, time and cost, which in turn leads to increased work output. Innovation is also a way of finding ways to create exciting products or services either through modifications or improvements. It is a result of creative and innovative ideas in any aspect of the work that can improve the quality and productivity of individuals or organizations. These ideas can be obtained from within and outside or through research and development processes as new ideas or adapted to be applied according to the needs of departments or organizations (MAMPU, 2010).

Without the practice and training of these innovative and creative skills in organizational management, there are some organizational staff, whether public or private, who have not found a solution to a problem and can not handle the challenges well because of uncertainty and do not practice outside the box. Thus, organizations can not grow well even organizational staff become less motivated every time they face problems and challenges. Organizational staff are also less interested and do not work in the work because they are always looking at problems and challenges from one perspective point of view. The overly autocratic management style is generally not favorable for the idea of nurturing, rather than the democratic management style of which most decisions are made in compromise and consensus (Awang, 2011). An organization needs more radical approaches and ideas to enable a more efficient and effective delivery of service delivery.

If an organization does not practice innovation and creativity in management, it must be difficult to achieve a change in the goals that are dreamed and still in the old notch. This is because there is no encouragement in generating fresh new ideas that can be used in organizational development. Individuals with innovative and creative abilities will look at problems, challenges and opportunities from a different angle. This situation is triggered by the desire of those who always want solutions in every matter they face and the situations they need to deal with. According to Mohd. Azhar Abd. Hamid (2004), an autocratic management style and less emphasis on two-way communication will cause the environment and the 'mood' of workers to decline. The effectiveness of productivity or job creation by employees does not achieve the targeted objectives. Hence, various measures and efforts need to be applied in the inculcating of innovative and creative management in order to create a healthy, comfortable and good working environment for employees of the organization.

\section{Problem Solving}

A stream of thought that has innovative and creative skills is needed as today's organization faces many complex challenges following the social and economic changes of the world. This environment demands the Department's delivery system so that the services rendered are more innovative in order to meet the expectations and reach out to the needs of our customers and stakeholders. Hence, there are five key strategies in nurturing creativity and innovation in organizational management.

First, employees in an organization need to be critical and constructive in carrying out their responsibilities by finding creative and innovative solutions, reaching out to the thinking and courage to experiment using new work methods, out of the human box. The second strategy is to improve 
INTERNATIONAL JOURNAL OF ACADEMIC RESEARCH IN BUSINESS AND SOCIAL SCIENCES Vol. 8, No. 7, July 2018, E-ISSN: 2222-6990 @ 2018 HRMARS

the service delivery system with a more innovative front line, which is in line with the transformation program's goal of creating a new engine to implement change and build momentum in delivering great wishes to customers immediately. The third strategy is to enrich the values of innovation and creativity in the environment and work culture within the organization. The fourth strategy is the individual who is skilled and knowledgeable. The last strategy is to carry out various activities for the innovation culture, to encourage organizational staff to provide opportunities and opportunities for organizational members, to voice things to solve any work problems or innovative proposals that can enhance the organization's service delivery system (MAMPU, 2010).

The basic elements of innovation for any organization are innovation beginning with the sensitivity to all things and things in the environment, especially about the things that people love and the things that are troublesome and hated by humans; improve the comfort and quality of any thing and thing that is favorable to humans and otherwise reduce the problem of users and clients; consensus and discussion of information and facts derived from users, clients, communities and the environment; barrier jumping and courage to try unique and odd ideas; the desire to innovate, the atmosphere that drives innovation and participation due to the fun of doing new things and creating new names and expectations about the future.

It is part of the organization through the encouragement of the idea, as managers open the door to suggestions and proposals from the workers. It's a good idea to use creativity among colleagues, giving them the opportunity to grow. It can also break down a pattern of non-functioning behavior and feel proud to speak. As a manager, finding ways to recognize and remember creative and innovative moments from day to day teamwork (Laruccia, 2009). Creativity is the key to innovation. With the growing competition between organizations, to stay active and to meet other organizations, every organization should encourage their employees to have creative and innovative skills so that they contribute satisfactorily and revolutionize the company. Spaces and opportunities should be given by top management to employees to donate creative ideas. In the context of employer-employer relationships, employers need to nourish the spirit of creativity among its employees, as well as to combat the common mental constraints among organizational members that hinder the process of creative thinking such as fear of failure, fear of being criticized, fear of risk and so forth.

In addition, examples of innovative and creative practices in management particularly in the office are by adopting the recycling concept, 3R Reuse (reuse), Reduce (recycling) and Recycle (recycling). Reuse is an activity using materials used for other uses. For example, use both sides of the paper before discarding, repair damaged equipment and discarded clothing donations. Reduction is an activity limiting the amount of waste generated. Reduce excess purchases of goods and packaging to control the production of more garbage or buy items in bulk. Recycling is an activity for reprocessing of used materials to produce new materials. This process can save on natural resources and energy. The proposal to carry out recycling activities in the office is to collect all materials that can be recalled every Monday in each unit or administrative building. Appoint a coordinator who will help monitor recycling activities. Paper grinding machine or known as 'shredder' should be provided for processing confidential and official documents. All the recyclable materials that have been collected should be weighed and recorded. Cash payments can then be made through a responsible division of the organization's welfare fund (Southern Waste Management, 2018). In addition to cost 
INTERNATIONAL JOURNAL OF ACADEMIC RESEARCH IN BUSINESS AND SOCIAL SCIENCES Vol. 8, No. 7, July 2018, E-ISSN: 2222-6990 @ 2018 HRMARS

savings, this recycling activity can also produce an individual disciplined and loving hygiene and avoid wastage.

Paper recycling culture in the office environment will be the starting point as well as changes in applying recycling culture among workers. Application of this culture in the office will also inculcate this practice while at home. The innovative and creative culture of practice and training can also be done through the use of technology. Today's sophisticated technological advances provide a variety of platforms to facilitate our daily life. Innovative and creative management in reducing the handling and use of paper papers in the office can be implemented using the management of electronic records in the digital application of the Document Management System (DDMS) in public offices. This procedure will assist the public office in dealing with transitions and changes in record management from conventional environments to electronic environment. In addition, this procedure can also help civilize civilization management of electronic records among employees.

The Digital Document Management System (DDMS) project is one of the government initiatives for projects under Entry Points Projects (EPP) e-Government, Paperless Government Implementation. The project is being implemented in stages throughout the public sector from 2013. It is aimed at enhancing the delivery of services and record-keeping as well as transparency of government services through the use of ICT technology. This application is capable of managing electronic records throughout the life cycle of records from creation to disposal. Creating records using this application procedure can be used almost all types of records such as files, guides, emails, charts, reports, meeting feedback, memos, minutes of meetings, proceedings and more (National Archives of Malaysia, 2013). Apart from saving paper usage, cost and paper handling time can also be reduced and work becomes easier and faster. Implementation of DDMS applications throughout the public sector can support the government's intention of reducing paper usage in government daily affairs as well as establishing uniform electronic records management across the public sector (National Archives of Malaysia, 2013).

\section{Research Impact}

The innovation of creative ideas and innovative ideas in the field of work can improve quality and productivity to the organization. The idea comes from various aspects and may include changes in the form of systems and procedures, methods and methods of working or technology introduction. An innovation can also benefit the people and can add value to organizations and organizational staff on existing conditions. The resulting value-added can distinguish an individual from another individual, whether in terms of service quality, production and demand for products or services delivered.

In addition, the work environment and culture within the organization should lead to the enrichment of innovation and creativity values. Changes in attitudes to inculcate the culture of innovation and creativity within the organization should start from the top leadership. Organizational management should be creative and innovative in order to ensure that the values of creativity and innovation are truly appreciated and become the working culture of all members within the organization. Too autocratic management style needs to be minimized so that there is a conducive atmosphere for creative. Democratic management style must be a practice because it can stimulate the growth of innovation culture and creativity within the organization. 
INTERNATIONAL JOURNAL OF ACADEMIC RESEARCH IN BUSINESS AND SOCIAL SCIENCES

Vol. 8, No. 7, July 2018, E-ISSN: 2222-6990 @ 2018 HRMARS

For the management of public services, the Innovation and Creative Group (KIK) was established as an effective management mechanism to build human capital in a highly skilled Public Service to realize the government's aspiration to increase the efficiency and effectiveness of Government agencies in delivering services to the people. According to KIK, there are some improvements and improvements in quality and productivity especially in the customer service delivery system after this guide is implemented. Among them is the ability to create new ways of working or innovation; the ability to solve problems or to improve work; teamwork spirit; seeding and applying value and positive work ethics; commitment and commitment to work; high working motivation; awareness of responsibility for oneself, group, organization and country; encouraging the creation of innovative and creative ideas and the existence of harmonious relationships between management and employees (MyGovernment, 2017).

\section{Conclusion}

Therefore, transformation must be made so that staff within the organization, regardless of which sector can produce productive workers and indirectly improves the image of the organization and the country. More planned efforts need to be made to develop the culture of innovation and creativity in the public and private sectors in line with the government's aspiration, the national transformation agenda must be innovative and creative. Effective management of knowledge enables organizations to share and value the knowledge base generated in the process of innovation. In conclusion, everything planned is needed to develop the culture of innovation and creativity in the organization.

\section{References}

Ahmad, P.K. (1998). Culture and Climate for Innovation. European Journal of Innovation Management. Volume 1. Number 1.1998. Retrieved from http:// www.emerald insight.com. Retrieved on 14 July 2018.

Amabile, T.M. (1996). Creativity and Inovation in Organizations. Harvard Business School Publishing. Retrieved from www.emerald insight.com. Retrieved on 12 July 2018.

Arkib Negara Malaysia. (2013). Tatacara Pengurusan Rekod Elektronik dalam Aplikasi Digital Document Management System (DDMS) di Pejabat Awam. Retrieved from http://www.ump.edu.my/edasar/pendaftar/doc/pengurusanrekod/rekod/Tatacara_Pengurusan_R ekod_Elektronik_dalam_Aplikasi_DDMS.pdf. Retrieved on 15 July 2018.

Awang, I. (2011). Memupuk Budaya Kreatif dan Inovatif Sektor Awam. Utusan Online. Retrieved from http://ww1.utusan.com.my/utusan/info.asp?y=2011\&dt=1108\&sec=Rencana\&pg=re_07.htm.

Retrieved on 16 July 2018.

De Gregori, W. (1994). Os Poderes dos seus Três Cérebros (Otaknya Kuasa Tiga). São Paulo: Pancast.

Hamid, M.A.A. (2004). Kreativiti: Konsep Teori dan Praktis. Penerbitan UTM, Skudai, Johor. Retrieved from http://library.oum.edu.my/oumlib/node/583128. Retrieved on 16 July 2018. 
INTERNATIONAL JOURNAL OF ACADEMIC RESEARCH IN BUSINESS AND SOCIAL SCIENCES Vol. 8, No. 7, July 2018, E-ISSN: 2222-6990 (C) 2018 HRMARS

MAMPU. (2010). Panduan Peningkatan Budaya Inovasi dalam Perkhidmatan Awam. Unit Pemodenan Tadbiran dan Rancangan dan Perancangan Pengurusan Malaysia (MAMPU). Jabatan Perdana Menteri. Retrieved from http://www.doa.gov.my/index/resources/aktiviti_sumber/sumber_awam/maklumat_pertanian/tek nologi_inovasi/panduan_peningkatan_inovasi_jan2010.pdf. Retrieved on 16 July 2018.

MyGovernment. (2017). Kumpulan Inovatif dan Kreatif. Retrieved from https://www.malaysia.gov.my/public/cms/article/page/826/. Retrieved on 16 July 2018.

Southern West Management, (2018). Separation at Source. Retrieved from http://www.swmenvironment.com/3r/separation-at-source-sas/. Retrieved on 14 Julai 2018.

Zakaria, Z.L. (2014). Semarakkan Kreativiti Budayakan Inovasi. Pusat Pengurusan dan Penyelidikan Inovasi. Dimensikoop Bil.14/2014. Retrieved from http://www.mkm.edu.my/images/Awam/Penerbitan/Dimensi_Koop/DimensiKoop44/semarakkan_ kreativiti_budayakan_inovasi.pdf. Retrieved on 16 Julai 2018. 